\title{
建て替えによる集合住宅の空間特性の変化が自主緑化に与える影響
}

一自主緑化を誘発する集合住宅の計画手法に関する研究一

\section{THE EFFECT OF CHANGE IN SPATIAL CHARACTERISTICS ON VOLUNTARY GREENING BY REBUILDING OF MULTIPLE DWELLING HOUSES}

-A study on design method for inducing voluntary greening in multiple dwelling houses-

生川，慶一郎*，柏 原士 郎**，吉 村英祐***，横田隆司****, 阪田弘一*****

Keiichiro NARUKAWA, Shiro KASHIHARA, Hidemasa YOSHIMURA, Takashi YOKOTA and Koichi SAKATA

\footnotetext{
This study aims to clarify the effect of change in spatial characteristics on voluntary greening by rebuilding of multiple dwelling houses. We investigated the actual conditions of voluntary greening both before and after the rebuilding by the questionnaire survey for the residents in rebuilt rental houses. The results are as follows:

1) Voluntary greening in balcony tends to be induced by increase of balcony area and connection with habitable room.

2) Voluntary greening in the common use corridor including in, space around front door tends to be deterred by return after the rebuilding from terraced houses and disconnection with habitable room.
}

Keywords: Voluntary greening, Spatial characteristics, Balcony, Space around the front door,

Multiple dwelling house, Questionnaire survey

自主緑化、空間特性、バルコニー、玄関前、集合住宅、アンケート調査

\section{1、研究の背景}

地球規模での環境破壊が深刻な問題になってきている今日、す心゙ ての分野において環境対策に取り組んでいかなければならない。こ のことは建築分野においても同様であり、省エネルギー、建物の辰 寿命化、環境八の影響が少ない建築材料の採用、リサイクル、廃椠 物削減、環境保全・景観形成などさまざまな方面からの環境負荷を 減らす方策が模索されている。このような状況の中、これらす心゙て に貢献する手法の一つとして建物緑化が注目されている。建物緑化 には日射の遮蔽による省エネルギ一効果、劣化防止や建物の保護効 果、空気清浄効果などに代表される物理的環境改善に寄与する効果 があるだけでなく、豊かさ安らぎ感の问上、園芸療法などの住民の 精神的環境改善にも頁献しているとの報告がある久1、2。しかし、現 実に行われている建物緑化は屋上緑化や壁面緑化などに代表される 物理的環境改善を市眼においており、住戸の居住環境とは直接関係 ない場合が多い。その結果、建物緑化による効果を住民が身近に感 じられず、イニシャルコストや維持管理なども負担になり、建物緑 化が促進されにくくなると考えられる。

そこで、これからの建物緑化のあり方を考えるにあたり、精神的 環境改善によるメリットから住民が自主的に維持管理を行えるよう な居住施設の緑化も一つの方向性として重要になると考えられる。

\section{2. 研究の目的}

集合住宅のバルコニーや共用廊下などに植木鉢やブランターが所 狭しと飾られ、豊かな緑空間が演出されている光景を見かける。こ のような住民による自主的な䐂化（以後、自主緑化洁1と呼ぶ）が行 われる背景として、集合住宅の住戸近傍部分注2 2 に緑化が可能である 未利用な空間が多く残されており、特別な技術を必要とすることな く、日常的な自主管理が可能であることが考えられる。

集合住宅において自主緑化が増加することは、物理的・精神的環 境改善に奇与するだけでなく、これまで生活の感じられない寒々し い殺風景な表情を呈していることが多かった集合住宅の住戸近傍部 分にも住民の関心が问くようになり、下町の路地に見られるような 近隣の人々との触れ合いのある防犯性の高い安全な住環境の形成に もつながるかい、と考えられるなど、その意義は多岐にわたる。

本研究は、集合住宅に扮いて自主緑化を誘発寸る計画手法のあり 方に関する研究文ら、6、テの一環として、公団賃貸集合住宅の建て替え 前後の住戸近傍部分の空間特性の変化と,自主緑化の奏態の変化を比 較することにより、空間特性の変化が自主緑化にどのような影響を 与えるのかを明らかにし、建て替え後も建て替え前と同様もしくは それ以上に自立緑化が楽しめる豊かな居住環境を計画するために必 要な空間特性を探ることを目的としている。
* 大阪大学大学院工学研究科 博士後期課程 $\cdot$ 修士 (工学)

*** 大阪大学大学院工学研究科教授・工博

**** 大阪大学大学院工学研究科, 助教授 $\cdot$ 博士 (工学)

*****大阪大学大学院工学研究科・助教授・博士 (工学)

***** 京都工芸㵶維大学工芸学部造形工学科 助教授・博士 (工学)
Graduate School of Eng., Osaka Univ., M. Eng.

Prof., Graduate School of Eng., Osaka Univ., Dr. Eng.

Assoc. Prof., Graduate School of Eng., Osaka Univ., Dr. Eng.

Assoc. Prof., Graduate School of Eng., Osaka Univ., Dr. Eng.

Assoc. Prof., Kyoto Institute of Technology, Dept. of Architecture and Design, Dr. Eng. 


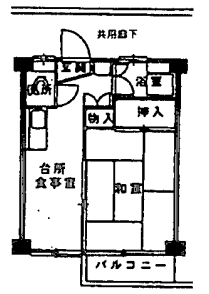

(a) $1 \mathrm{DK}-1: 37 \mathrm{~m}^{2}$ パコニー面程: $2.6 \mathrm{~m}^{2}$

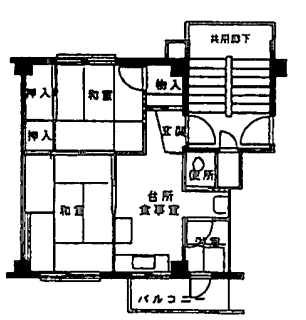

(f) $20 \mathrm{~K}-4: 43 \mathrm{~m}^{2}$ 价コ二-面矰: $3.3 \mathrm{~m}^{2}$

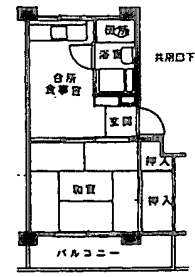

(b) $10 K-2: 32 \mathrm{~m}^{2}$ 汭コニー面积: $5.1 \mathrm{~m}^{2}$

仙コニ一面称: $3.6 \mathrm{~m}^{2}$

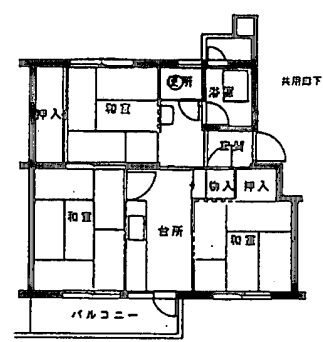

(g) $3 \mathrm{~K}: 50 \mathrm{~m}^{2}$ ハルコニー面积: $6.1 \mathrm{~m}^{2}$ 階段室型 (c) $2 \mathrm{DK}-1: 44 \mathrm{~m}^{2}$

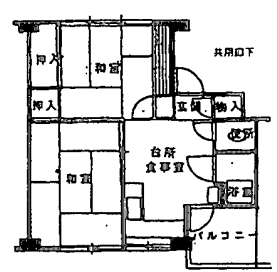

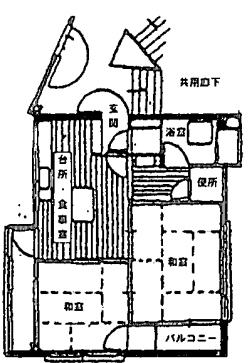

(d) $2 D K-2: 50 \mathrm{~m}^{2}$ 沉コニー面积: $3.4 \mathrm{~m}$

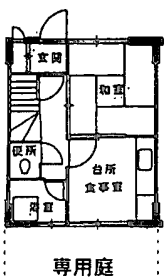

1F平面図

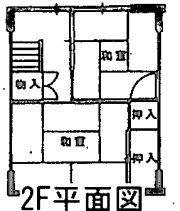

(h) $3 \mathrm{DK}: 50 \mathrm{~m}^{2}$ 専用庭: 約 $20 \mathrm{~m}^{2}$ 長屋型式

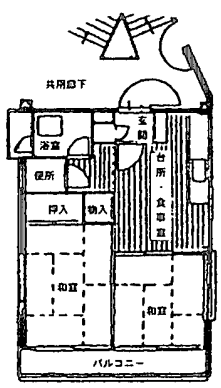

(e) $20 K-3: 52 \mathrm{~m}^{2}$ バコニー面稆: $5.4 \mathrm{~m}^{2}$ 階段室型

图1、図2の凡例
住宅型式：住戸面䅡 住戸に僢接する尃用部分

\section{: 尃用面穓}

住戸へのアクセス型式

(図1のa,b...hと图2 のA, B...Iは対応して いない。)

$\frac{2 m}{3 m}{ }_{1 m}^{\text {mim }}$

図1 A団地の建て替え前の住宅型式
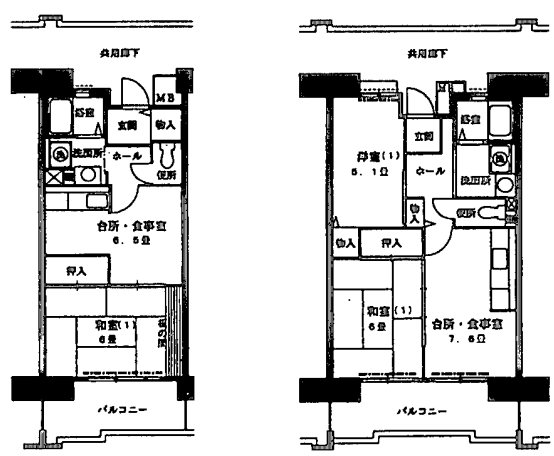

(A) $1 \mathrm{DK}: 35 \mathrm{~m}^{2}$ ハルコニー面艋 片廊下型

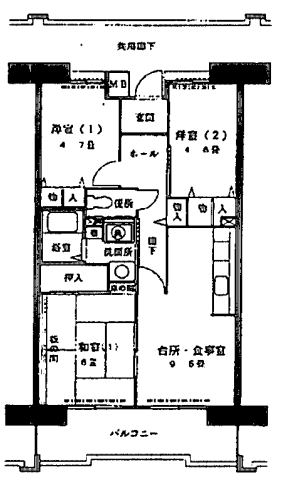

(F) $3 D K-1: 62,63,66 \mathrm{~m}^{2}$ ハルコニー面程 片廊下型
(B) $\begin{aligned} & 2 \mathrm{DK}-1: 47 \mathrm{~m}^{2} \\ & \text { バルコニー面租 }\end{aligned}$ バルコニー面程
$: 8.9 \sim 10.0 \mathrm{~m}^{2}$ 片廊下型

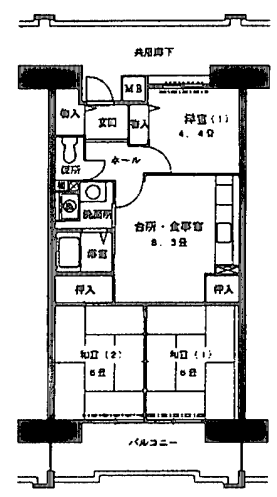

(G) $3 D K-2: 57,58 \mathrm{~m}^{2}$ バココー面积 汸部下型
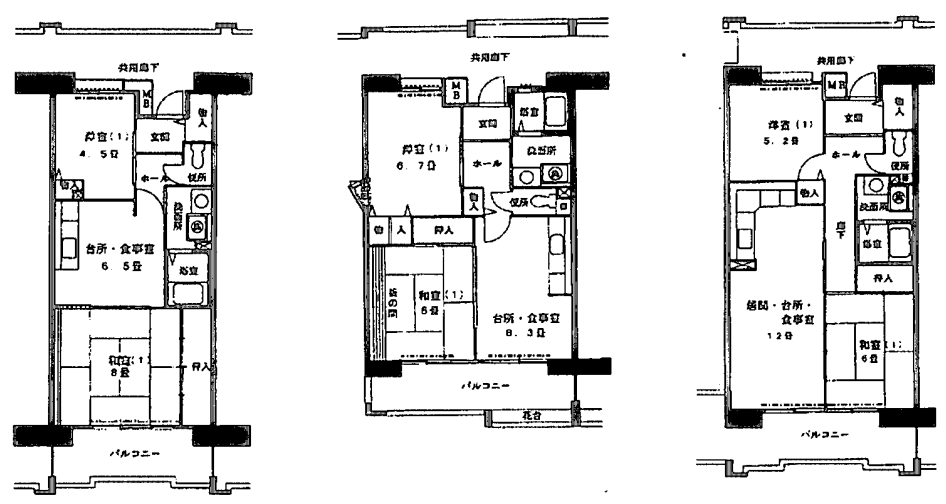

(C) $2 \mathrm{DK}-2: 49 \mathrm{~m}^{2}$ ハルコニー面程 片廊下型

(D) $2 \mathrm{DK}-3: 53 \mathrm{~m}^{2}$ ハルコニー面程 :9.1 $12.4 \mathrm{~m}^{2}$

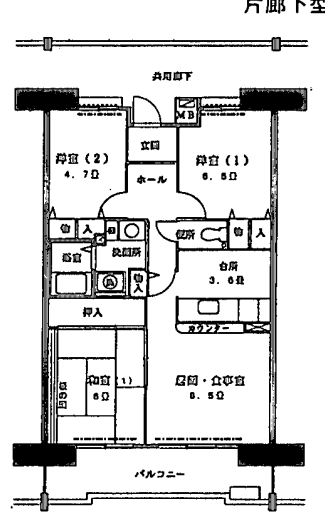

(H) 3 LDK: $69 \mathrm{~m}^{2}$ バルコニー面程
$: 9.1 \sim 21.6 \mathrm{~m}$ 片廊下型
(E) $2 \mathrm{LDK}: 58,59 \mathrm{~m}^{2}$ バコニー面糟 片廊下型

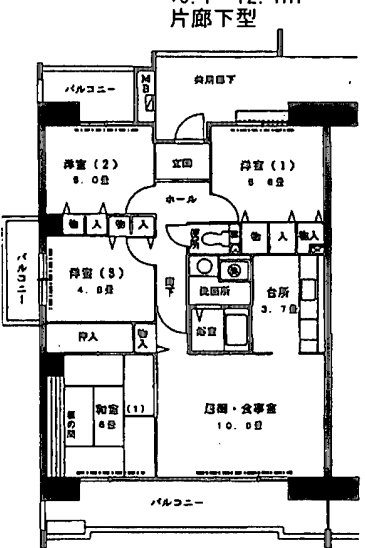

(I) $4 \mathrm{LDK}: 83 \mathrm{~m}^{2}$ ハルコニ一面軣 片廊下型

図2A団地の建て替え後の住宅型式 


\section{3. 研究対象および研究方法}

\section{3-1 研究対象の選定}

建て替えが実施された集合住宅であれば、建て替え前後の両方の 住戸近傍部分の空間特性および自主緑化の実態を比較することがで きる。さらに、その建て替え計画が戻り入居を前提としていること、 2000 年 (平成 12 年) 1 月の時点で戻り入居世帯が 659 世帯で全居住 世帯数（753 世帯）の約 $86 \%$ を占奴り、建て替え前後において 世帯構成があまり变化していないことから、世帯構成の変化による 影響を受けない空間特性の変化が自主緑化の実態に与える影響を探 ることができる。以上の二点から：戻り入居を前提に建て替えが実 施された公団賃貸集合住宅を研究対象として選定した湔。

\section{3-2 研究方法}

まず、記名アンケート調查により回答世帯の調査時点の世帯主年 齢、建て替え前後の世带構成および住宅型式を把握する湔。次に、 研究対象は戻り入居が大半を占めていることから、世帯構成が建て 替え前後において変化していない回答世帯を抽出する。以上のよう に、世帯属性の特定できる回答世帯に限定して建て替え前後におけ る住戸近傍部分の空間特性の変化と自主粶化の実態の変化を把握し、 それらを比較することで、世帯構成の変化による影響を受けない空 間特性の変化が自主緑化の実態に与える影響を明らかにする。

\section{4. 研究対象および研究方法}

\section{4-1 調査対象の概要}

調查対象は大阪府北部に立地する公団貨貸集合住宅（以後 $\mathrm{A}$ 団地 と呼ぶ）で、1958 年（昭和 33 年）に入居が開始された。建て替え事 業は 1995 年（平成 7 年） 5 月に始まり、2004 年（平成 16 年） 3 月に 完了する計画で、最終的に住戸数は 1333 戸になる予定である。入居 状況は 1997 年（平成 9 年） 3 月に第 1 次募集が始まり、同年 10 月に 第 2 次募集、1999 年（平成 11 年）10月に第 3 次募集が行われ、2000 年（平成 12 年）1月に行った調查の時点では戻り入居が 659 戸、一 般公募が 94 戸で合計 753 戸であった。立地条件としては、鉄道沿線 や主要幹線道路から少しはずれているため比較的静かな住宅地で、 団地の周辺には大規模な公園があることから緑も豊富であり自然環 境には恵まれていると考えられる。

基本的に建て替え前は片廊下型、階段室型と長屋型式で、建て替 え後は片廊下型のみの住棟からなる集合住宅である。建て替え前後 の調查対象の主要な住宅型式沛を図1、図2に示寸。

\section{4-2 調查方法}

集合住宅の住戸近傍部分に扔ける自主緑化の実態拉よび緑化場所 としての住戸近傍部分に対する住民の評価を把握するため、以下に 示す四つの項目にういてA 住宅の住民にたず㸚た。ただし、(3)、(4) に関しては現在、住戸近傍部分に自主緑化を行っている住民に限っ てたずねた。

(1) 住民に対して現在の自主緑化の有無

(2) 緑化場所としての住戸近傍部分の利用実態

(3) 緑化場所としての住戸近傍部分に対する評価

(4) 緑化場所としての住戸近傍部分に対する不满点

アンケートは、平成 12 年 1 月時点で A 団地に入居している住戸(753 可)の山で家貨滞納者を除くす心゙ての玄関扉の郵便受けに平成 12 年 1 月'29 月投函した。回答は団地内の集会所に併設された管理サービス
センターの郵便受けに投函してもらい、随時回収した。

\section{4-3 回収状況}

全回答世帯数は 533 世帯で全居住世帯数（753 世帯）の約 $71 \%$ で あったが、その中でも建て替え前後で世帯構成が変わっておらず。 建て替え前後の住宅型式が特定できる有効回答世帯数は 378 世帯で 全居住世帯数（753 世帯）の約 $50 \%$ であった。

\section{4-4 回答世帯の属性}

まず、回答世帯の世帯主の年齢層别にみた世帯構成の分布を図 3 に示す。ただし、世帯構成の分類としてく夫婦十子供〉、〈夫婦の み $>、\langle$ 単身 $>$ 、〈その他 $>$ の 4 タイプを考え、以後の図中の世帯 主年齢は記名アンケート調查時点（2000 年1月）のものとし、[ ]内 の数值は世帯数の実数とする。図 3 より $50 \sim 59$ 歳 (116 世帯) が最 も多く、次いで 60〜69 歳（93 世帯）、70〜79 歳（66 世帯）となっ ていることがわかる。また、世帯構成との関倸について、69 歳以下 では＜夫婦＋子供＞の占める割合が高いのに対し、70 歳以上になる とく単身 $>$ 、〈夫婦のみ $>$ 占める割合がく夫婦十子供 $>$ 上りも高 くなっている。

回答世帯の建て替え前後の住宅型式と世帯構成の分布を図 4 、図 5 に示す。住宅型式の分布について、建て替え前は (g) 3K. (96 世帯) が 最も多く、次いで(f) 2DK-4（69世帯）、(c) 2DK-1（65世帯）となっ ているのに対し、建て替え後は (H) 3LDK（87 世帯）が最も多く、次い で(F) 3DK-1（73 世帯）、.(B) 2DK-1（65世帯）となっている。

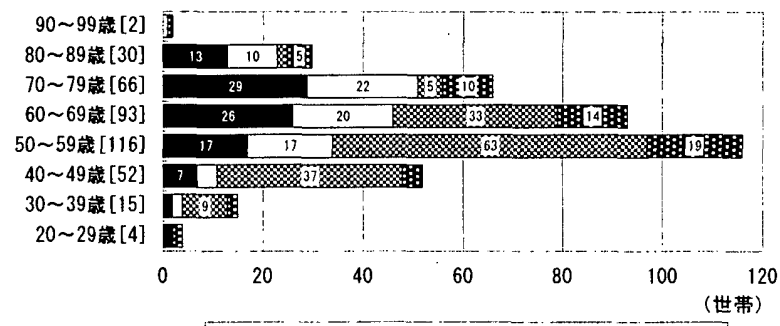

単身口天婦のみ两婦十供丽その他 図3 世帯主年撂と世帯構成の分布
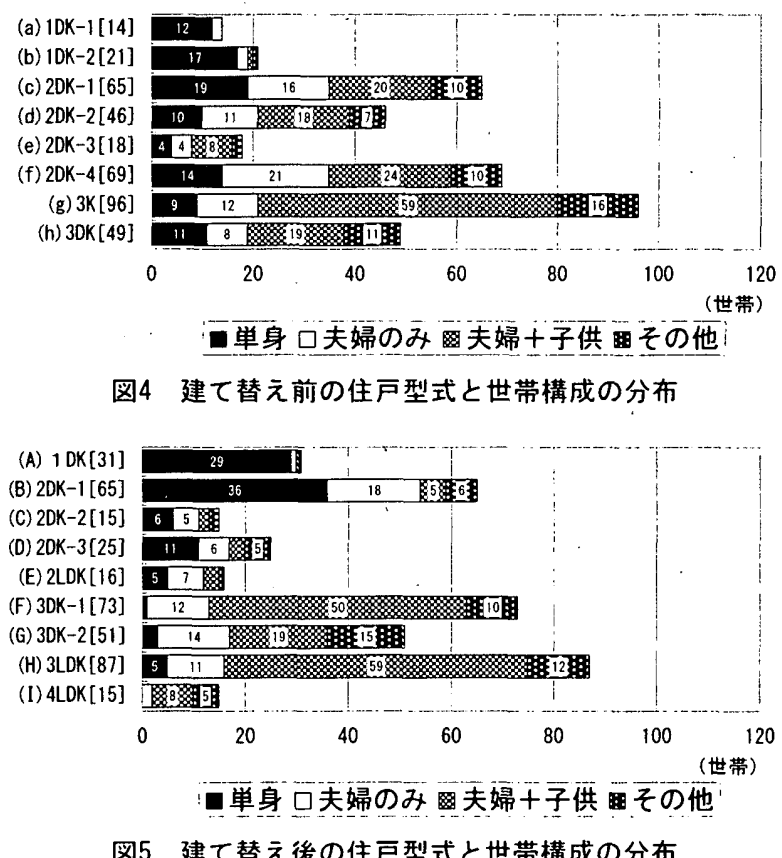
このことから、建て替え前は㾛室として利用できる部屋数が 2 室の 住宅型式が多かったが、建て替え後は 3 室の住宅型式が多くなって おり、住宅型式の規模が全体として大きくなったことがわかる。ま た、世帯構成の分布について、建て替え前の場合、〈単身〉は (a) 1DK-1、 (b) 1DK-2 に偏ることなく他の住宅型式にも住んでおりく夫婦十子供 $>$ くいては $(\mathrm{g}) 3 \mathrm{~K}$ に最も多く住んでいるのに対し、建て替え後の場 合、<単身>は (A) 1DK、(B) 2DK-1 に、<夫婦十子供>については 3DK 以上にその大半が住んでいることがわかる。このことから、建て替 え前に㾛室として利用できる部屋数が 3 室の住宅型式に住んでいた く単身 >の多くは、永年住んできた結果として家族の死別や子供の 独立などにより建て替え時点で一人暮らしになってしまったと考え られ、建て替え後は家貨が高くなった、高齢化などの理由で建て替 え前より小さい住宅型式に移り住んでいると思われる。逆に瘦室と して利用できる部屋数が 2 室の住宅型式に住んでいたく夫婦十子供 >の多くは、建て替え後家貨が多少高くなったとしても、建て替え 前よりもよりもよい住環境を求めて 3 室の住宅型式に移り住んでい ると思われる。

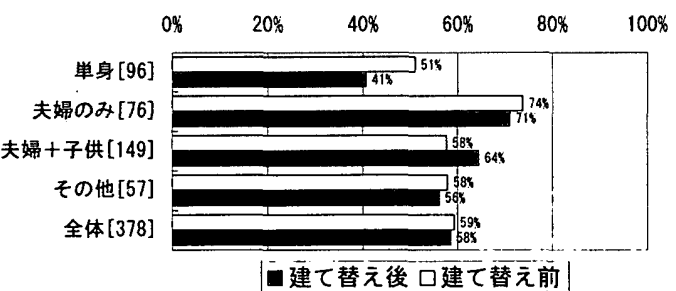

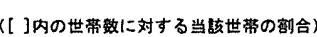
図6世帯構成別にみた建て替え前後の自主緑化の実態

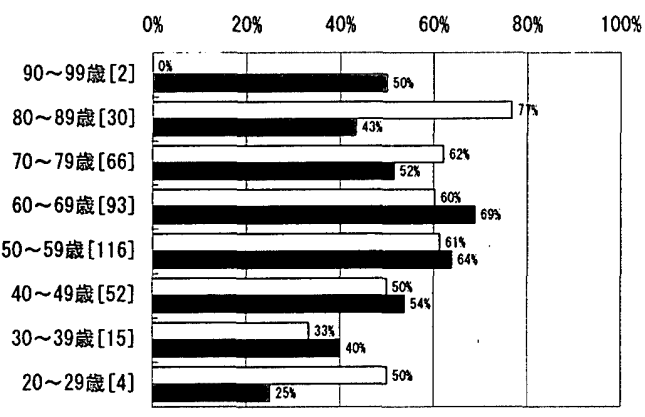

建て替え後口建て替え前

([ ]内の世带致に当影世整の剽合

図7世带主年龄別にみた建て替え前後の自主緑化の実態

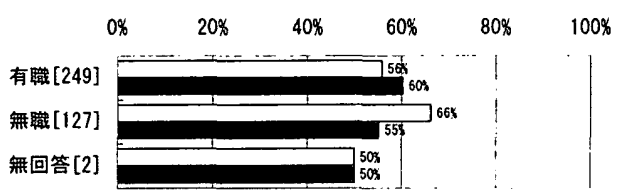

四建て替え後口建て替え前

图8 世带主の瞕業有無別にみた犍て替え前後の自主緑化の突態

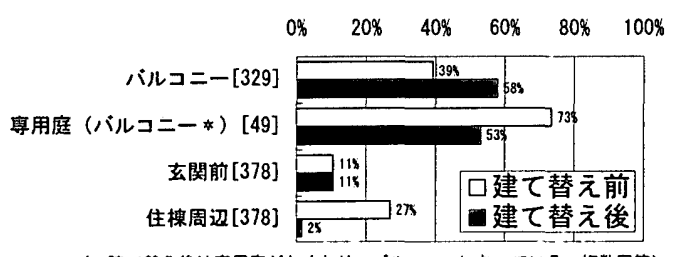

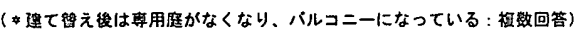
図10 建て替え前後の自主緑化場所の変化

\section{5. 䂸て替え前後の自主緑化の実態}

5-1 世帯属性別の自主緑化の実態

世帯構成別にみた建て替え前後の自主緑化を行っている世帯の割 合を示したものが図 6 である。全体としては建て替え前が $59 \%$ 、建 て替え後は $58 \%$ であまり変化がみられない。世帯構成別にみた場合、 く夫婦のみ>は建て替え前後でそれぞれ $74 \% 、 71 \%$ と最も高いのに 対して、く単身〉は建て替え前後でそれぞれ $51 \% 、 41 \%$ となってお り、最も低くなっている。また、く夫婦十子供〉の場合は建て替え 後自主緑化を行っている割合が增加しているのに対し、く単身>の 場合は減少している。その理由として、4-4で述べたように建て替え

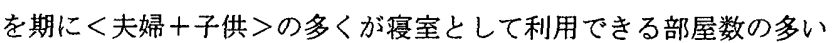
住宅型式に移り住んだため空間的余裕が生まれ、逆にく単身 >は寝 室として利用できる部屋数の少ない住宅型式に移り住んだため空間 的余裕がなくなったことが考えられる。

世帯主年齢層別にみた建て替え前後の自主緑化を行っている世帯 の割合を示したものが図 7 である。建て替え前は 80〜89 歳 $(77 \%)$ が最も高かったのに対し、建て替え後は60〜69歳（69\%）が最も高 くなっている。その理由として、世帯主が 70 歳以上の高噛世帯にな ると急に加齢による体力の低下を感じ始め、建て替えを機に自主緑 化を止めてしまうことが考えられる。
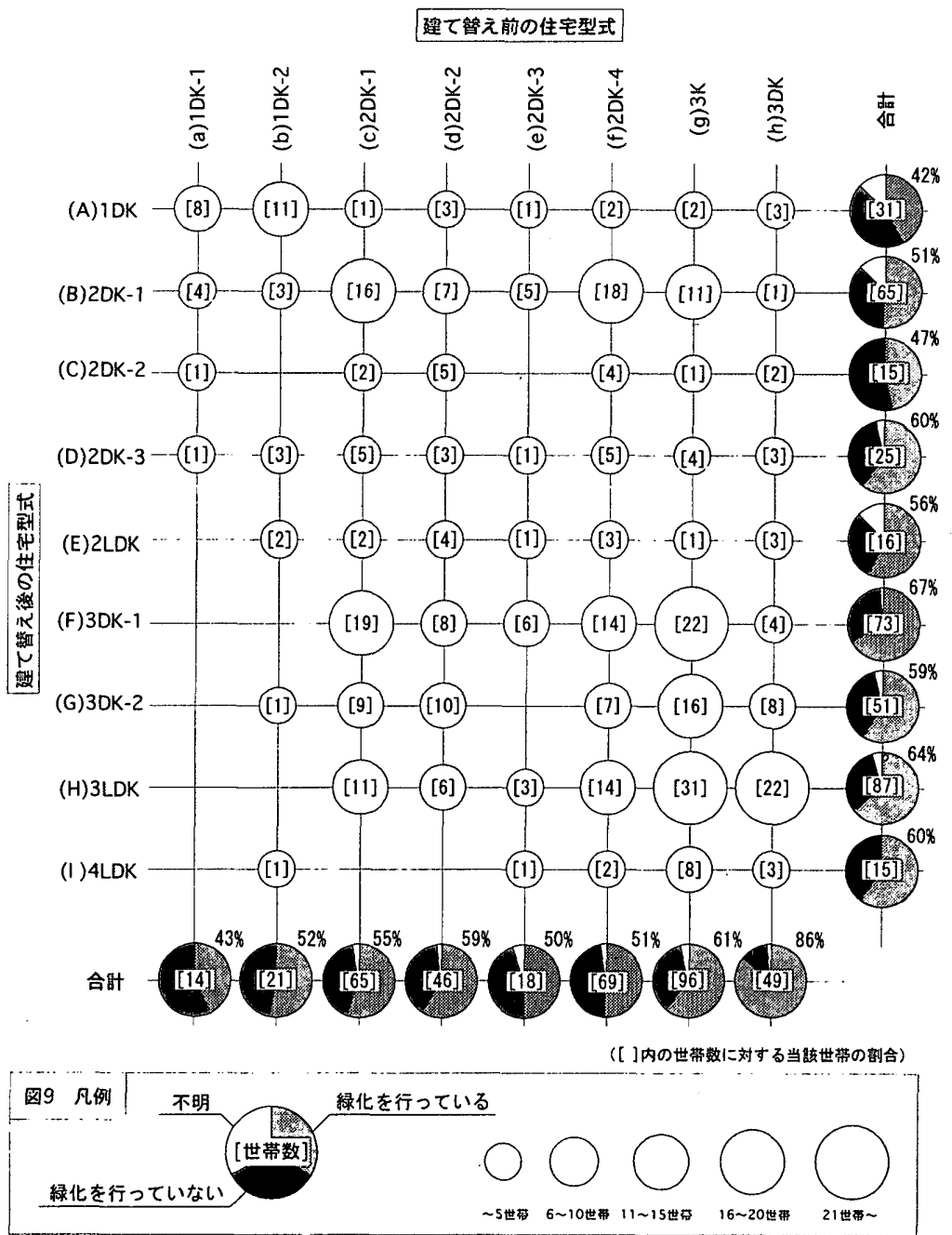

図9建て替え前後の住宅型式別にみた自主緑化の実態 
世帯主の職業有無別にみた建て替え前後の自主緑化を行っている 世帯の割合を示したものが図 8 である。建て替え前後を比較すると 建て替え後は世帯主が有職の場合は 4 ボイント増加し、無職の場合 は10 ポイント減少した結果、建て替え後は世帯主が有職で自主緑化 を行っている世帯の割合が無職で自主緑化を行っている世帯の割合 を上回り、建て替え前と比べ逆転している。このことは、建て替え による居住環境の変化が、平均的に時間的余裕のあると思われる高 齢世帯に㧍ける自主緑化を抑制し、平均的に時間的余裕の少ないと 思われる若年、中年世帯における自主緑化を誘発している可能性を 示唆している。

\section{5-2 住宅型式別の自主緑化の実態}

建て替え前後の住宅型式別にみた自主緑化を行っている世帯の割 合を図 9 に示す。住宅型式別の自主緑化を行っている世帯の割合は、 建て替え前の(h) 3DK が群を抜いて高くなっているのを除けば、建て 替え前後ともに瘦室として利用できる室数が多い住宅型式になるほ ど少し高くなる傾向がみられる: 建て替え前の(h) 3DK が他の住宅型 式に比べ非常に高くなっている理由として、約 $20 \mathrm{~m}^{2}$ の専用庭が設け られていることが考えられる。

\section{5-3 緑化場所としての住戸近傍部分の利用実態}

建て替え前後について各住戸近傍部分が緑化場所として利用され る割合を示したものが図 10 である。ただし、建て替え後には専用庭 の設けられている住宅型式はない。建て替え前は住戸近傍部分の中 で専用庭 $(73 \%)$ が利用される割合が圧倒的に高く、ついでバルコ ニー $(39 \%)$ 、住棟周辺 $(27 \%)$ となっている。建て替え後はバル コニー（建て替え前の住宅型式にバルコニーがあった場合 $58 \%$ 、専 用庭の場合 $53 \%$ ) が最も高く、ついで立関前（11\%）となっている。 また、住棟周辺が自主緑化に利用される割合が建て替え前より建て 替え後の方が低くなっているのに対して、バルコニーが利用される 割合が建て替え前より建て替え後の方が高くなっている。その理由 として、建て替え前の住棟周辺は裸地部分が多くて住民が自主的に 住棟周辺に花壇・菜園をつくる場所があったが、建て替え後はほと んど隙間無く植栽や歩道などが整備されてしまい、住民が自主緑化 を行える場所がなくなってしまったことに加えて、バルコニー面積 （専用庭を除く）が建て替え前より建て替え後の方が大きくなった ことにより、バルコニーがサービスヤードとしての用途以外の自主 緑化などにも利用できる空間的余裕が生まれたことが考えられる。

\section{5-4 緑化場所としての住戸近傍部分の評価}

アンケートでは、現在、自主緑化を行っている世帯（267世帯）に 自守緑化を行う視点から見た住戸近傍部分に対する住民の满足度を たずねた。その結果、図11に示されるように31\%の世帯が住戸近傍 部分に詨して「やや不満である」または「不满である」と評価して いる。また、「やや不満である」または「不満である」と評価して いる世带 (84 世帯) を対象に、その具体的な不満点についてもたず 好、その結果を図 12 に示す。「バルコニーが狭い（35世帯）が最 も多く、次いで「住棟周辺に十の見えている部分が少ない」(34世 帯）、「住棟周辺に花壇・菜園を造る場所がない（32世帯）、「外 にある撒水栓や水道を水やりに使えない（26 世帯）、「住棟周辺 に樹を植える場所がない（22 世帯）、「玄関前のスベースが狭い (15世帯) となっている（複数回答）。このことから、バルコニー が狭いことや住棟周辺に住民が自由に使える場所がないことに対寸
る不満が多くなっていることがわかる。

また、自由回答欄に举げられていたその他の不満点を整理したも のを表 1 に示す。バルコニーに水栓が設置されていないこと（建て 替え前に住んでいた住戸には水栓が設置されていた）、バルコニー の休に防水が施されていないこと、バルコニーの排水孔が自住戸の バルコニー内にないため污れた水が隣の住戸に流れてしまうこと、 バルコニーに吹き込む風が強く植木鉢がすぐに乾燥してしまい水分 不足となるなど、バルコニーに対する不満が多く挙げられている。

\section{6. 空間特性の変化がバルコニー緑化に与える影翌}

建て替え前後のバルコニー面積の変化をみてみると、建て替え前 は2. 6〜6. $1 \mathrm{~m}^{2}$ (専用庭を除く) であったのに対し、建て替え後は 6.6 〜25. $5 \mathrm{~m}^{2}$ と大きくなっていることがわかる。また、建て替え前後の バルコニーおよび専用庭側の間取りの変化をみてみると、建て替え 前のバルコニーおよび専用庭に面している台所、食事室、和室、浴 室などの位置関係が各住宅型式で少しずつ異なっていることからバ ルコニーと住戸の多様な関係がみてとれるのに対して、建て替え後 は和室、台所・食事室（居間）を中心とした間取りに限られている ことがわかる。以上のことから、バルコニー緑化に影響を与えると 考えられる建て替え前後の空間特性の変化としで少なくとも、(1) ルコニーの広さ、(2)バルコニー側の間取りの二つが考えられる。

\begin{tabular}{|c|c|c|c|c|c|}
\hline \multicolumn{3}{|c|}{$555_{i}$} & & & 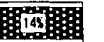 \\
\hline $0 \%$ & $20 \%$ & $40 \%$ & $60 \%$ & $80 \%$ & $100 \%$ \\
\hline
\end{tabular}

(綝化を行っている267世带中)

図11 自主緑化を行う視点からみた住戸近傍部分に対する満足度

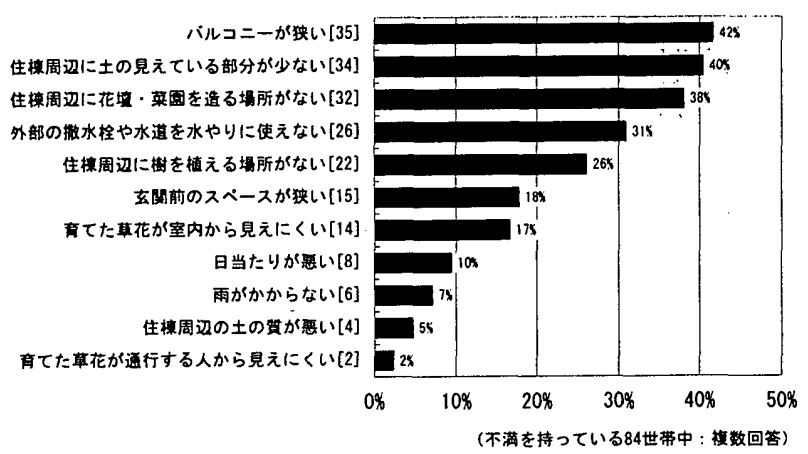

図12 自主緑化を行う視点からみた住戸近傍部分に対する不満点

表1 自由回答欄に挙げられていた不満点

\begin{tabular}{|c|c|}
\hline \multirow{6}{*}{ 旪画に閃するもの } & 只ルコニーに水栓が钤罢されていない（5)* \\
\hline & ハイコニーに防水跑装が施されていない（3） \\
\hline & 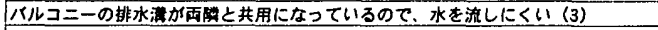 \\
\hline & イルコニーで水やりをした帱の水はけかか墨く、水たまりがでをでをににくい（1） \\
\hline & 花台が能しかった (1) \\
\hline & 花を舌くとふとんが干しにくい(1) \\
\hline \multirow{6}{*}{ 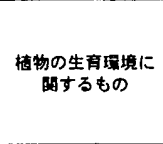 } & 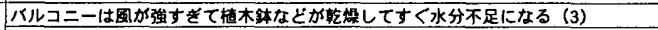 \\
\hline & 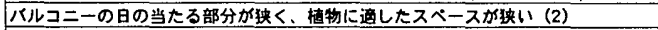 \\
\hline & 选扫物を干す之㥀物に日光が当たらない (1) \\
\hline & イルコニーでは草花加育ちにくい(1) \\
\hline & 温度、風速の变化など境的に真ちにくい条件（1） \\
\hline & 国通しが慗い (1) \\
\hline \multirow{4}{*}{ 安全性に開するもの } & 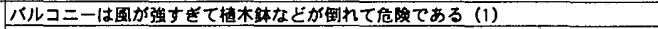 \\
\hline & 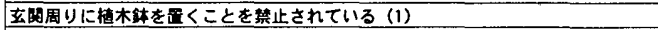 \\
\hline & 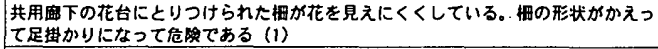 \\
\hline & 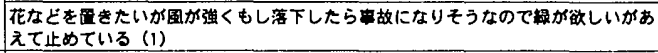 \\
\hline その地 & 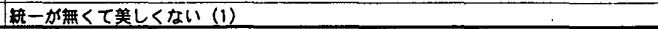 \\
\hline
\end{tabular}


6-1 パルコニー面積の変化がバルコニー緑化に与える影響

建て替え前後におけるバルコニー面積の変化と、建て替え前後と もにバルコニー緑化を行っている世帯、建て替え住宅に移り住んで からはじめた世帯、建て替え住宅に移り住んでからやめてしまった 世帯、建て替え前後ともに行っていない世帯の構成比率の関係をみ てみる。図13に示されるように、建て替え前からバルコニーの設け られている住宅型式に住んでいた場合はバルコニー面積が増加する 量が大きくなると建て替え後緑化をはじめる世帯の割合が若干では あるが高くなっている。それに比べて、建て替え前は専用庭の設け られていた住宅型式に住んでいた場合には、最も建て替え後バルコ

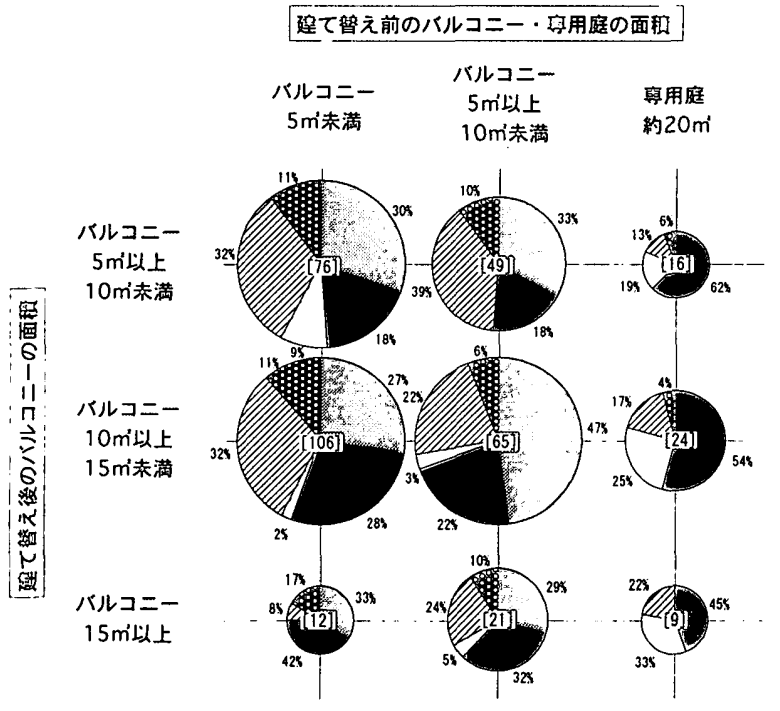

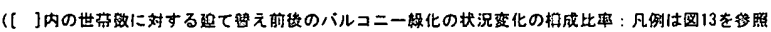

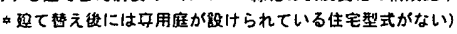

图13 バルコニー* 面積の変化がバルコニー緑化に与える影響
ニー緑化をはじめた世帯と建て替え後緑化を止めてしまった世帯の 両方の割合が最も高くなっている。このように、バルコニーの設け られている住宅型式を住みこなしてきた場合にはバルコニー面積が 增加するとバルコニー緑化が誘発される傾向がみられるが、建て替 え後はじめてバルコニーの設けられている住宅型式に移り住んだ場 合には、建て替え前の習慣の継続としてバルコニー緑化をはじめる 世帯もあれば、団地内から団地外の他の場所の貸農園に緑化場所を 移したり、専用庭がなくなってしまったことをきっかけに全く止め てしまう世帯などがあると考えられる。

6-2 バルコニー側の間取りの变化がバコニー緑化に与える影響

建て替え前後におけるバルコニー側の間取りの変化と建て替え前 後ともにバルコニー緑化を行っている世帯、建て替え住宅に移り住 んでからはじめた世帯、建て替え住宅に移り住んでからやめてしま った世帯、建て替え前後ともに行っていない世帯の構成比率の関倸 をみてみる。図 14 に示されるように、建て替え前にバルコニーが室 内にとり込まれていてサンルームのようになっていた (d) $2 \mathrm{DK}-2$ と (e) 2DK-3に住んでいた世帯は、建て替え住宅に移り住んでからバル コニ一緑化をはじめた割合が高くなっていることから、バルコニー 緑化を誘発するためにはバルコニーが室外にあることが重要である と考えられる。また、建て替え前のバルコニー側の間取りが台所お よび浴室に限られていた (c) 2DK-1、(f) 2DK-4に住んでいた世帯が、 建て替え後すべてバルコニーが和室に面する住宅型式に移り住んで いる。このことが建て替え後住宅に移り住んでからバルコニー緑化 をはじめた世帯の割合が高くなっている一因と考えられる。以上の ようにバルコニーが台所や浴室に面しているよりも、和室などの居 室に面している方がバルコニー緑化を誘発する傾向がみられる。

\section{室て㚙え前のパルコニー側の間取り}

(a) 1DK-1

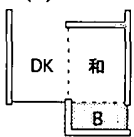

(b) 1 DK-2

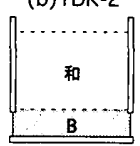

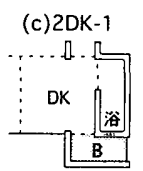
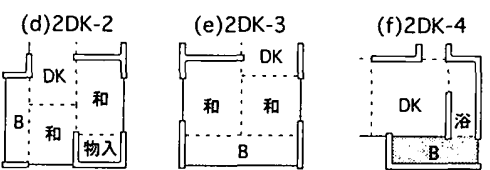

(g) $3 \mathrm{~K}$

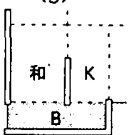

(h) $3 \mathrm{DK}$
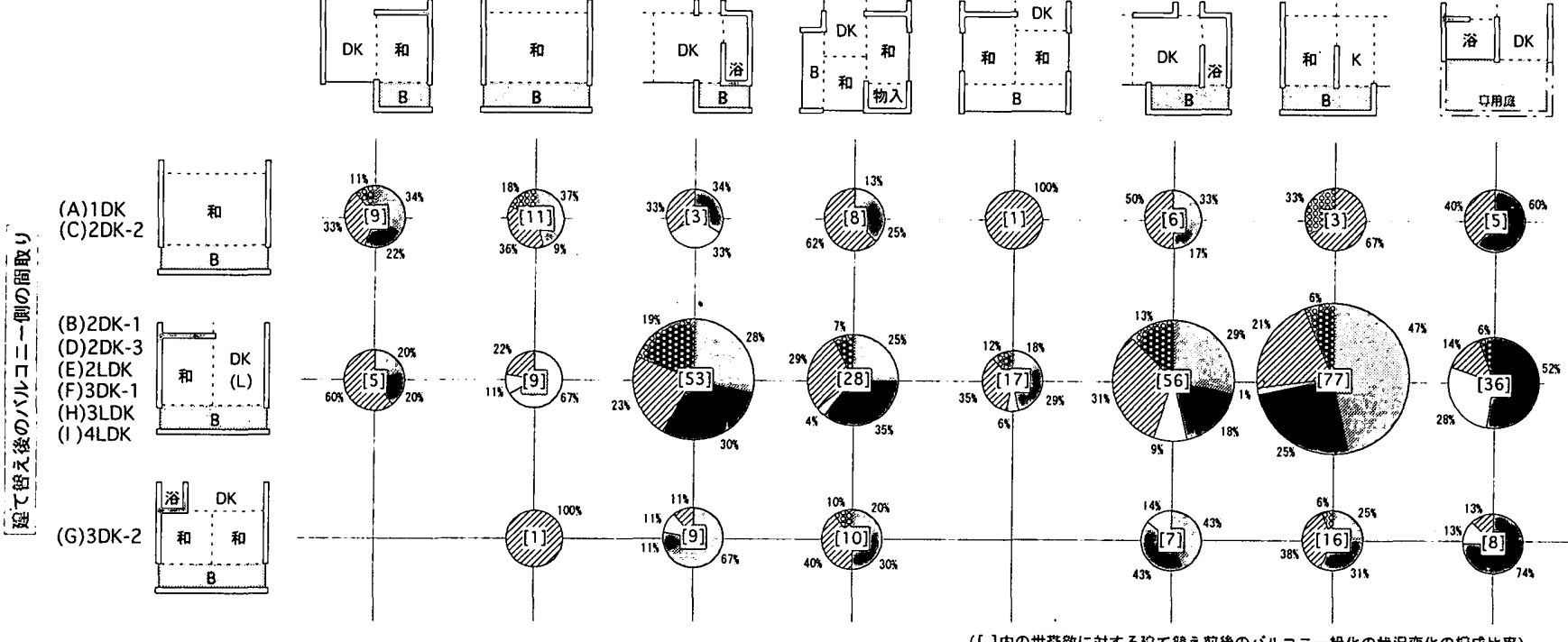

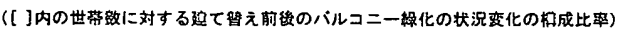
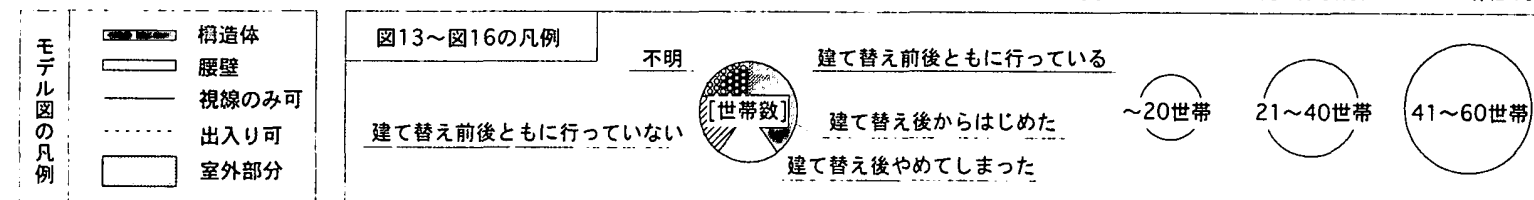

61 世带〜

図14 バルコニー側の間取りの変化がバルコニー緑化に与える影響 


\section{7. 共用廊下側の空間特性の変化が玄関前緑化に与える影賠}

建て替え前後の居住階数の変化をみてみると、建て替え前は最高 階数が 5 階の住棟型式と長屋型式です心゙て中低層のものしかなかっ たのに対して、建て替え後は一つの住棟が低層の 3 階建てであるこ とを除けば残りの寸心゙てが 5 10 階建てで中高層の住棟型式になっ ている。また、建て替え前後の共用廊下側の間取りの変化をみてみ ると、建て替え前の住戸の共用廊下側にはほとんど開口部が設けら れておらず、浴室・便所が面しているのが 14 戸、和室が面している

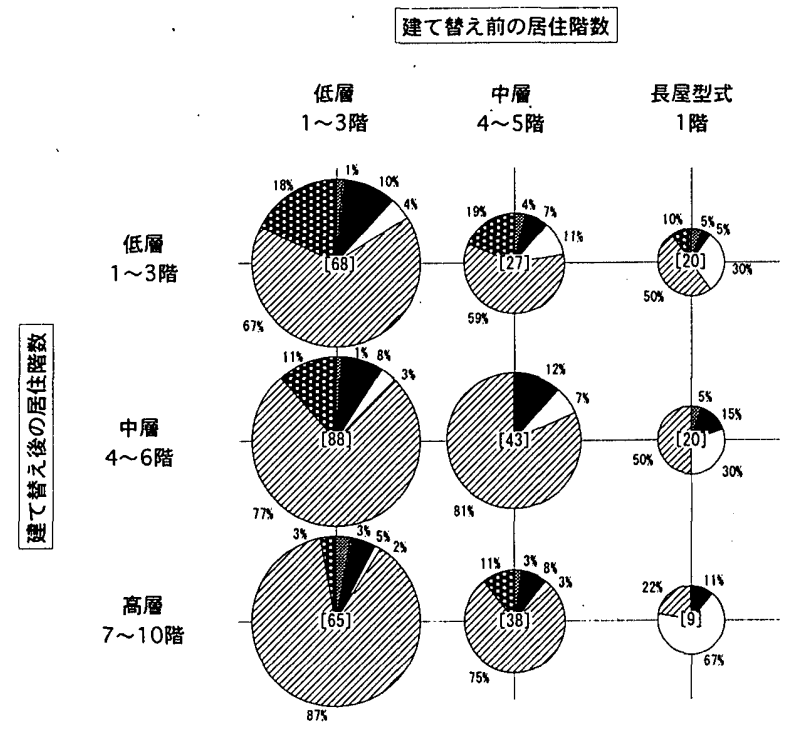

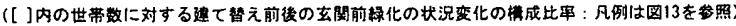
図15 居住階数の变化が玄関前緑化に与える影響

\section{建て替え前の共用颜下側の間取り}

(b) 1 DK-2 (e)2DK-3 (c) $2 D K-1$ (f) $2 \mathrm{DK}-4$ (d) $2 D K-2(\mathrm{~g}) 3 \mathrm{~K}$

(a) 1 DK-1

(h) $3 D K$

$$
\text { なし }
$$

谷室·便所

和室

(A) $10 K$
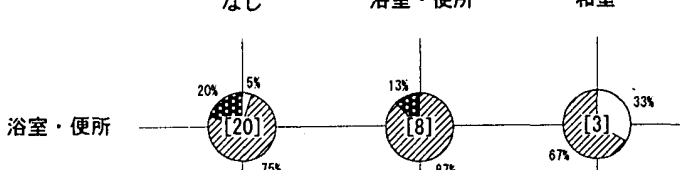

(C)2DK-2

(G)3DK-1

洋窒
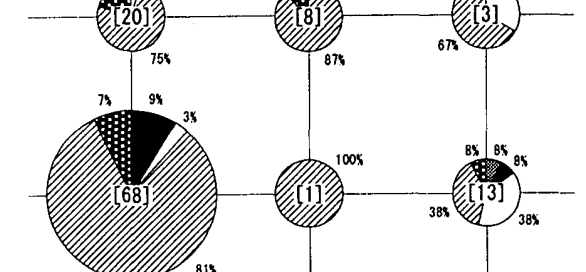

(B)2DK-1 洋室

(D) $2 D K-3$ 浴室·便所
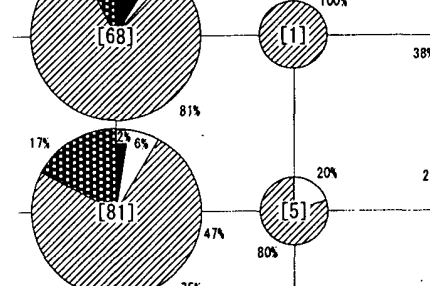

(F)3DK-1

(H) 3 LDK

洋室2室

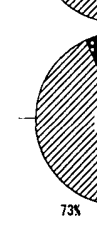

(1) 4LDK

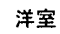

行き止まり
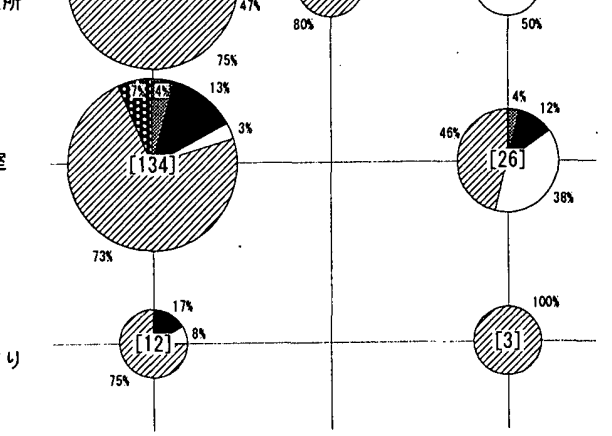

図16 共用廊下側の空間構成の変化が玄関前緑化に与える影響 ([ ]内の世带数に対する建て替え前後の玄関前緑化の状況变化の構成比率：凡例は図13を参照）
のが 49 戸であるのに対して、建て替え後では 347 戸の約 $92 \%$ の住戸 で洋室が面している。以上のことから玄関前緑化に影響を与えると 考えられる建て替え前後の空間特性の変化として少なくとも、(1)居 住階数、(2)共用廊下側の間取りの二つが考えられる。

\section{7-1 居住階数の変化が玄関前緑化に与える影響}

建て替え前後の居住階数の变化と建て替え前後ともに玄関前緑化 を行っている世帯、建て替え住宅に移り住んでからはじめた世帯、 建て替え住宅に移り住んでからやめてしまった世帯、建て替え前後 ともに行っていない世帯の構成比率の関倸をみてみる。ただし、1階 から 3 階を低層、4 階から 6 階を中層、7 階以上を高層とする。

図 15 に示されるように、建て替え前の居住階数が低層の場合、建て 替え後移り住む居住階数が高層になるほど、若千ではあるが玄関前 緑化を建て替え住宅に移り住んでからはじめる世帯の割合が低くな る傾向がみられる程度で、建て替え後中高層の住棟型式になったと しても全住棟にエレベーターが設けられているためか、全体的には それほど居住階数により大きな差異はみられない。しかし、建て替 え前に長屋型式に住んでいた場合は、建て替え後立関前緑化をやめ てしまった世帯の割合が非常に高くなっている。

\section{7ー2 共用廊下側の間取りの变化が玄関前緑化に与える影響}

建て替え前後における共用廊下側の間取りの変化と建て替え前後 ともに玄関前緑化を行っている世帯、建て替え住宅に移り住んでか らはじめた世帯、建て替え住宅に移り住んでからやめてしまうた世 帯、建て替え前後ともに行っていない世帯の構成比率の関係をみて みる。図16に示されるように、共用廊下側に開口部がない住宅型式 から共用廊下に洋室が面する住宅型式に移り住んだ場合、建て替え 住宅に移り住んでから立関前緑化をはじめた世帯の割合が高くなっ ている。また：共用廊下に和室が面する住宅型式から洋室が面する 住宅型式に移り住んだ場合は、建て替え後立関前緑化を止めてしま った世帯の割合が高くなっている。共用廊下に和室が面している住 宅型式は建て替え前の (h) 3DK のみであるが、この住宅型式は住棟型 式が長屋型式に限られているため、一概に共用廊下に面する居室が 洋室よりも和室の方が立関前緑化を誘発しているとはいえない。以 上のように、共用廊下側に開山が設けられていない場合よりも居室 が面している方が玄関前緑化を誘発する傾向がみられる。

\section{8. まとめ}

本研究により、A 団地を対象に行った自主緑化に関するアンケート により明らかになったことは、下記の通りである。

（1）住民の属性からみると、建て替え前後ともに、〈夫婦のみ>が 最も多く自主緑化を行っているのに対し、〈単身〉ではあまり行わ れていなかった。また、建て替え前は世帯方の年龄が調查時点（平 成 12 年 1 月) で 80 89 歳の世帯が最も自立緑化を行っている割合 が高かったが、建て替え後は50〜59 歳の世帯が最も高くなっていた。 （2）建て替え前の約 $20 \mathrm{~m}^{2}$ 専用庭が設けられている(h) 3DKで自主緑 化を行っている割合は他の住宅型式に比心゙圧倒的に高くなっていた。 また、住戸近傍部分の中でも專用庭が緑化場所として利用される割 合も最も高くなっていた。

（3）建て替え前は、緑化場所として専用庭、バルコニー、住棟周辺 の順にほぼ住戸近傍部分全般にわたって利用されていたが、建て替 え後は住棟周辺の利用が極端に減少してバルコニーにその利用が集 
山していた。その理由として、建て替え前の空き地のような住棟周 辺が建て替え後にはほとんど隙間無く植栽や歩道などで整備されて しまったため住民が自由に花壇や菜園を作れるような場所がなくな ってしまったこと、建て替え後のバルコニ一面積が建て替え前に比 ぶ大きくなったことが考えられる。このことから、建て替え後のバ ルコニー面積の增加が建て替え前から習慣として続けてきたと考え られる自主緑化を許容するよい結果を生んでいると考えられる。

（4）自主緑化を行う視点から住戸近傍部分を評価した場合、自主緑 化を行っている世帯の約 3 割が「やや不満である」または「不満で ある」と感じている。その具体的な不満点としては「バルコニーが 狭いり「住棟周辺に花壇・菜園を造る場所がない、「玄関前のス ペースが狭いなど住戸近傍部分に自主緑化を許容するだけの空間 的余裕がないことが多く举げられていた。

（5）建て替え前の住戸でバルコニーに面する室が台所および浴室に 限られてしまっていた (c) 2DK-1、（f) 2DK-4に住んでいた世帯が、建 て替え後すべてバルコニーが和室に面する住宅型式に移り住んだ結 果、バルコニー緑化をはじめた世帯の割合が高くなっている。この ようにバルコニーが台所や浴室に面しているよりも、居室に面して いる方がバルコニー緑化が多く行われる傾向がみられた。

（6）建て替え前の居住階数が低層の場合、建て替え後の居住階数が 高層になると若干ではあるが玄関前緑化を建て替え住宅に移り住ん でからはじめる世帯の割合が低くなり、長屋型式に住んでいた場合 は建て替え後緑化を止めてしまった世帯の割合が高くなっている。

（7）共用廊下側に開山部がない住宅型式から共用廊下に洋室が面す る住宅型式に移り住んだ場合、建て替え後緑化をはじめた世帯の割 合が高くなっている。このことから、共用廊下に居室が面すること によって玄関前緑化が多く行われる傾向がみられた。

以上のことは、集合住宅において自立緑化を誘発するには、住戸 近傍部分に空間的余裕を確保すること、住戸近傍部分に居室が面す るように計画することが重要であることを示唆している。今後の課 題としては、住戸近傍部分と総称しているバルコニー、共用廊下、 住棟周辺の個々において、自衣緑化の実態を綿密に観察調査し、住 民に対するヒアリングを併用しながら、各部分に対する自主緑化を 誘発する具体的な計画手法を提案していく必要があると考えている。

\section{謝辞}

アンケート調查に協力していただいた A 団地の住民の方々に深く 感謝いたします。また、今回の調查全般において協力をしていただ いた都市基盤整備公団の関西支社の方々にも心より感謝の意を捧げ ます。

\section{注}

1）住民が自主的に花墑・菜園などを造ったり、植木鉢やブランターなどを1 個以上置くこと,

2）住戸の室内部分以外で住民が住戸の延長として利用される可能性のある 住戸迴りのスベースである。具体的にはバルコニ一、共用廊下、住棟周辺 などが举げられる：他には、植木鉢やブランターなどが圈ける場所として 花台が一部の住棟の妻側の空の外、および一部の住戸のバルコニー内に設 けられている、しかし、妻側に花台が設けられている住戸は16 棟（753 戸) の中で 2 棟（16戸）しかなく、非常に数が少ないため今回の調查項目には 含めていない:また、バルコニー内に設けられている花台はバルコニーの 手寸り壁と一体化しており、住民が緑化場所としてバルコニー上花台を明 確に使い分けしていない可能性が大きいと考えられることから、本論では
バルコニーとバルコニー内に設けられている花台を区別していない。

3）建て替え前から A 団地の前身である団地に住んでいて、建て替え後も A 団地に再び入居すること。ただし、戻り入居には、(1)先工区にお住まいで 後工区の住宅または他の公団住宅に仮移転が必要な場合（約 2 年間）と(2) 後工区にお住まいの方で仮移転が不要な場合の 2 種類がある。

4）本研究は建て替え後の居住性の評価を目的と寸る都市基盤整備公団の委 託研究の一環として行ったものである。

5）本アンケート調査は都市基盤整備公団の関西支社の協力を得て記名アン ケート調査が実施できたため、台帳と照合して建て替え前後の住民の住宅 型式を特定することができた。

6）都市基盤整備公団では $1 \mathrm{DK} 、 2 \mathrm{DK} 、 2 \mathrm{LDK} 、 3 \mathrm{~K} 、 3 \mathrm{DK} 、 3 \mathrm{LDK} 、 4 \mathrm{LDK}$ などの間 取りの分類を住宅型式と呼んでいることから、本研究はそれに従っている。

参考文献

1) (財) 都市緑化技術開発機棈 : NEO-GREEN SPACE DESIGN(2) 新・緑空間デ ザイン技術 マニュアル、誠文堂、1999

2）與水䜿：建築空間の緑化手法、彰国社、1998

3）鈴木成文：住まいを読む一現代日本住居論一、建築資料研究社、1999.2

4）小林秀樹：集住のなわばり学、彰国社、p，63、1992

5）生川慶一郎, 柏原士郎, 吉村英祐, 横田隆司，阪田弘一，佐野こずえ，大浦 睍登 : 実態調查に基づく集合住宅における緑化に対寸る居住者の意識につ いて一自主緑化を誘発する集合住宅の計画手法に関する研究一、地域施 設計画研究 18、pp. 267 274、2000.7

6）生川慶一郎，柏原士郎，吉村英祐, 横田隆司，阪田弘一，佐野二ずえ，大浦 寛登 : 集合住宅の玄関前における住民の自主緑化を誘発する空間特性につ いて、日本建築学会大会学術講演梗概集 E-2 分冊、pp. 217 219、2000

7）佐野こずえ，柏原士郎，吉村英祐，横田隆司，阪田弘一，林史朗：公共穓贷 環境共生住宅の居住者意識から見た環境共生手法の在り方 一環境共生型 集合住宅の計画手法に関寸る研究一、日本建案学会計画系論文集 第 537 号、 pp. $157 \sim 164 、 2000.11$

8）佐野こずえ，柏原士郎，吉村英祐，横田隆司，阪田弘一，林史朗: 環境共生住 宅に関する居住者の意識について一環境共生住宅の計画手法に関才る研 究一、日本建築学会大会学術講演梗概集 E-2 分冊、pp. 353 354、1999

9）高田光雄：日本における集合住宅計画の変遷、財団法人放送大学教育振 興会、1998. 3

10）豊田裕崇、高田光雄、Oussouby SACKO、岸川榇介：タイトル：実験集合 住宅 NEXT 21 の居住者と周边住民の建築物緑化に対才る印象 実験集合住 宅 NEXT 21 にお打る建築物緑化に関寸る調查研究 その 2 、日本建築学会 大会学術講演梗概集 E-2 分冊、pp. 349 350、1996

11）鈴木成文：現代住居の開放性・閉鎖性に関寸る実態調查と考察、神戸芸 術工科大学、 p. 185、1998

12）西沢文隆：西沢文隆小論集 2 庭園論 庭一その華麗なるもの[1] 人と庭 の建築の間、相模書房、1975

13）岩尾琵、市川智一、田中大輔：施設用途別にみた緑地の健全性に関寸る 考察、日本建築学会大会学術講演梗概集 F-1 分冊、pp. 747 748、1997

14）今津乃里子、西村一朗、中山徹：住民の緑行動に関寸る研究、日本建築 学会大会学術講演梗概集 F-1 分册、pp. 107 108、1998

15）神谷展行、須田真史、初見学：集合住宅における中間領域と近隣交際の 形成 一住戸の開放性が生活に及ぼ寸影響一、日本建築学会大会学術講演 梗概集 E-2 分冊、pp. 139 140、1999

16）今津乃里子、中山徽：緑とのふ九あいから見た高龄社会における余睱活 動に関才る研究、日本建築学会大会学術講演梗概集 F-1 分冊、pp. 901 902、 1999

17）黒見敏丈：磷家間コミュニケーションを促進する敷地境界緑地の南り方 に関才る研究 一タウン八ウス型住宅団地に扩ける居住者意識を通して一、 日本建勧学会大会学術講演梗概集 F-1 分冊、pp. 1035 1036、1999

（2001年 6 月 1 日原稿受理，2001年 9 月 27 日採用決定 